\title{
Effect of Castration on Urinary Excretion of a Gonadotropin-Inhibiting Substance in Rats*
}

\author{
MinORU OTA, KenRo WADA AND KiJuro OBARA \\ Departments of Biochemistry and Physiology, Iwate \\ Medical University School of Medicine, Morioka, Iwate
}

\section{Synopsis}

\begin{abstract}
The effect of castration on the urinary excretion of a gonadotropin-inhibiting substance was studied in male albino rats. Ovulation induced with PMS and HCC was not inhibited in mice which received a heated extract prepared from the urine of castrated rats, while the ovulation was inhibited in mice given a heated extract from the urine of intact rats. This finding indicates that the excretion of a gonadotropin-inhibitor is strongly suppressed in the urine of the rats which are castrated. Administration of testosterone to the castrated rats exerted no effect on the decreased excretion of the inhibitor. The present observations and the results obtained previously suggest that the pituitary and the testes are involved in the secretion of a gonadotropin-inhibitor from the pineal.
\end{abstract}

A substance with luteinizing hormoneinhibiting properties was demonstrated in the urine of albino male rats (Ota et al., 1970) and it was postulated that the pineal gland was a possible secreting organ of the inhibitor (Ota et al., 1971). Furthermore, it was suggested that the pituitary may be involved in the secretion of the inhibitor by the fact that ovulation induced with pregnant mare's serum gonadotropin (PMS) and human chorionic gonadotropin (HCG) was partially inhibited in mice receiving a heated extract from the urine of hypophysectomized rats (Ota et al., 1971).

The present study was made to investigate whether the excretion of a gonadotropininhibiting substance (GIS) is changed by castration in male rats and, furthermore, to investigate the effect of testosterone treatment on the excretion of GIS in the castrated male rats.

Received for publication February 5, 1972.

* This study was supported by a grant from the Population Council.

\section{Methods}

Eight week-old male rats of the Wistar strain were maintained in the animal room at a constant temperature of $23^{\circ} \mathrm{C}$. Overhead fluorescent lamps were kept on from 5:30 a.m. to 7:30 p.m. daily and each animal was exposed to approximately equal light intensities. Castration was performed at 9 weeks of age. In the first experiment, no treatment was given to the castrated rats. In the second experiment, $500 \mu \mathrm{g}$ of testosterone dissolved in $0.1 \mathrm{~m} l$ of olive oil per $100 \mathrm{~g}$ of body weight was injected subcutaneoulsy three times a week (Monday, Wednesday and Friday) to half of the castrated animals. To another animals, $0.1 \mathrm{~m} l$ of olive oil per $100 \mathrm{~g}$ of body weight was injected in the same manner as in the other group.

All animals were housed in cages, two animals to a cage, and urine collection was started at 10 weeks of age. This means that urine collection was begun on the 8 th post-operative day in the castrated animals. Pooled urine specimens obtained from each group for a week were diluted into $1.5 l$ with distilled water and extracted according to the tannic acid precipitation method of Johnsen (1958). The extract for injection was prepared and heated according to Ota et al. (1970).

The inhibitory effect of the extract was detected by the ovulation method using 21 day-old female 
mice of the ICR-JCL strain. As the control, 1.0 I.U. of PMS (Serotropin, Teikoku Zoki Co.) dissolved in $0.3 \mathrm{~m} l$ of $0.9 \%$ saline solution containing $0.2 \%$ bovine serum albumin was injected intraperitoneally at 4:00 p.m., followed by 0.5 I.U. of HCG (HCG-Mochida, Mochida Pharmaceutical Co. Ltd.) dissolved in $0.3 \mathrm{~m} l$ of $0.9 \%$ saline solution containing $0.2 \%$ bovine serum albumin at 2:00 p.m. on the third day. As the experimental, 1.0 I.U. of PMS was injected at 4:00 p.m. and 0.5 I.U. of HCG was injected with an extract equivalent to 3 days' urine from one rat at 2: 00 p.m. on the third day. The mice were killed at 9: 30-10:00 a.m. on the fourth day and the number of ova recovered from the oviducts was counted. The suppression of ovulation was considered as the evidence of the presence of the inhibitor.

\section{Results}

The body weights of the orchiectomized groups with and without testosterone were similar until 14-15 weeks of age, but an increase of the body weight was slightly higher in the orchiectomized rats received testosterone. Their body weight was lower than that of the normal rats.

There was no difference in urine volume between the intact rats (the average volume per day was $8.0 \mathrm{~m} l$ and $10.9 \mathrm{~m} l$ at $10-12$ and 12-14 weeks of age, respectively) and the castrated rats treated with testosterone (the average volume per day was $7.5 \mathrm{~m} l$ and $9.6 \mathrm{~m} l$ at 10-12 and 12-14 weeks of age, respectively), but the castrated rats treated with olive oil excreted a larger volume of urine (the average volume per day was $12.5 \mathrm{~m} l$ and $13.1 \mathrm{~m} l$ at 10-12 and 12-14 weeks of age, respectively). The specific gravity of the urine of the castrated rats treated with olive oil (1.043 at 1214 weeks of age) showed a lower value than the normal (1.060) and the testosteroneadministered castrated rats (1.056). The $\mathrm{pH}$ of the urine of the intact rats $(9.40$ at $12-14$ weeks of age) was almost similar to that of the castrated animals treated with oil (9.05) or with testosterone (9.03).

The weight of the residues obtained by extraction was $7.4 \mathrm{mg}, 6.8 \mathrm{mg}$ and $4.0 \mathrm{mg}$ at 14-16 weeks of age in the intact rats and the castrated rats with or without testosterone, respectively. It was noted that the weight of the residue in the castrated rats without the injection of testosterone was significantly lower than that of the intact rats.

The percentage of ovulated mice and the average of ova in the oviducts in the groups received the heated extract from the urine of intact and of castrated rats on the ovulation induced with PMS and HCG are shown in Table 1. There was significant inhibition of the ovulation induced with PMS and HCG in the mice received the heated urinary extract of the intact rats as shown a low percentage

Table 1. Inhibitory effect of the heated extract from the urine of intact and of castrated rats on the ovulation induced with PMS and HCG in mice

\begin{tabular}{|c|c|c|c|c|c|c|c|}
\hline $\begin{array}{c}\text { Source of } \\
\text { urinary extract }\end{array}$ & $\begin{array}{l}\text { Postopera- } \\
\text { tive period } \\
\text { at urine } \\
\text { collection }\end{array}$ & $\begin{array}{l}\text { Age of rats } \\
\text { at urine } \\
\text { collection }\end{array}$ & $\begin{array}{l}\text { No. of } \\
\text { mice }\end{array}$ & $\begin{array}{l}\text { No. of } \\
\text { ovulated } \\
\text { mice }\end{array}$ & $\begin{array}{c}\% \text { of } \\
\text { ovulation }\end{array}$ & $\begin{array}{l}\text { ova/mouse } \\
\text { (av. } \pm \text { S.E.) }\end{array}$ & $\mathrm{P} \S$ \\
\hline control $^{*}$ & & & 12 & 11 & 91.7 & $9.5 \pm 1.0$ & \\
\hline intact rats ${ }^{\dagger}$ & & 12-13 weeks & 12 & 4 & 33.3 & $1.3 \pm 0.5$ & $\mathrm{P}<0.05$ \\
\hline castrated rats ${ }^{\dagger}$ & 3-4 weeks & $12-13$ weeks & 11 & 9 & 81.8 & $7.8 \pm 1.1$ & $\mathrm{NS}(\mathrm{P}<0.25)$ \\
\hline intact rats ${ }^{\dagger}$ & & $14-15$ weeks & 11 & 5 & 45.5 & $4.0 \pm 1.3$ & $\mathrm{P}<0.05$ \\
\hline castrated rats ${ }^{\dagger}$ & $5-6$ weeks & $14-15$ weeks & 11 & 11 & 100.0 & $8.2 \pm 0.8$ & NS \\
\hline
\end{tabular}

* Each mouse received 1 I.U. of PMS followed by 0.5 I.U. of HCG in 46 hrs apart.

$\uparrow$ Each mouse, in addition to PMS plus HCG doses as above, received heated extract of equivalent to 3 days' urine.

$\S$ Level of statistical significance of the difference from the control: $\mathrm{NS}=$ not significant. 
Table 2. Inhibitory effect of the heated extract from the urine of intact and of castrated rats treated with or without testosterone on the ovulation induced with PMS and HCG in mice

\begin{tabular}{|c|c|c|c|c|c|c|c|}
\hline $\begin{array}{c}\text { Source of } \\
\text { urinary extract }\end{array}$ & $\begin{array}{l}\text { Postopera- } \\
\text { tive period } \\
\text { at urine } \\
\text { collection }\end{array}$ & $\begin{array}{l}\text { Age of rats } \\
\text { at urine } \\
\text { collection }\end{array}$ & $\begin{array}{l}\text { No. of } \\
\text { mice }\end{array}$ & $\begin{array}{l}\text { No. of } \\
\text { ovulaiton } \\
\text { mice }\end{array}$ & $\begin{array}{c}\% \text { of } \\
\text { ovulation }\end{array}$ & $\begin{array}{l}\text { Ova/mouse } \\
\text { (av. } \pm \text { S.E.) }\end{array}$ & $P \S$ \\
\hline \multirow{4}{*}{$\begin{array}{l}\text { control* } \\
\text { intact rats } \dagger \\
\text { castrated rats } \\
\text { received vehicle } \dagger \\
\text { castrated rats } \\
\text { received } \\
\text { testosterone } \dagger\end{array}$} & \multirow{4}{*}{$1-3$ weeks } & \multirow{4}{*}{$10-12$ weeks } & 6 & 6 & 100 & $12.5 \pm 1.0$ & \\
\hline & & & 6 & 2 & 33.3 & $1.3 \pm 1.8$ & $\mathrm{P}<0.001$ \\
\hline & & & 10 & 9 & 90 & $10.1 \pm 1.1$ & $\mathrm{NS}(\mathrm{P}<0.10)$ \\
\hline & & & 10 & 10 & 100 & $13.9 \pm 0.9$ & NS \\
\hline \multirow{4}{*}{$\begin{array}{l}\text { control* } \\
\text { intact rats }{ }^{\dagger} \\
\text { castrated rats } \\
\text { received vehicle }{ }^{\dagger} \\
\text { castrated rats } \\
\text { received } \\
\text { testosterone }{ }^{\dagger}\end{array}$} & \multirow{4}{*}{ 3-5 weeks } & \multirow{4}{*}{$12-14$ weeks } & 12 & 11 & 91.7 & $9.8 \pm 0.9$ & \\
\hline & & & 6 & 3 & 50.0 & $4.5 \pm 1.8$ & $\mathrm{P}<0.01$ \\
\hline & & & 12 & 10 & 83.3 & $7.3 \pm 1.1$ & $\mathrm{NS}(\mathrm{P}<0.08)$ \\
\hline & & & 12 & 10 & 83.3 & $8.3 \pm 1.0$ & NS \\
\hline \multirow{4}{*}{$\begin{array}{l}\text { control* } \\
\text { intact rats }{ }^{\dagger} \\
\text { castrated rats } \\
\text { received vehicle } \dagger \\
\text { castrated rats } \\
\text { received } \\
\text { testosterone }{ }^{\dagger}\end{array}$} & \multirow{4}{*}{ 5-7 weeks } & \multirow{4}{*}{ 14-16 weeks } & 12 & 11 & 91.7 & $10.3 \pm 1.2$ & \\
\hline & & & 6 & 0 & 0 & & $\mathrm{P}<0.001$ \\
\hline & & & 12 & 10 & 83.3 & $8.4 \pm 1.3$ & $\mathrm{NS}(\mathrm{P}<0.30)$ \\
\hline & & & 12 & 11 & 91.7 & $9.2 \pm 1.4$ & NS \\
\hline
\end{tabular}

* Each mouse received 1 I.U. of PMS followed by 0.5 I.U. of HCG in 46 hrs apart.

$\uparrow$ Each mouse, in addition to PMS plus HCG doses as above, received heated extract of equivalent to 3 day's urine.

$\S$ Level of statistical significance of the difference from the control: $\mathrm{NS}=$ not significant.

of ovulation and a decreased number of ova per mouse as compared to that of the control mice received only PMS and HCG. On the other hand, no inhibition of the ovulation was found in the groups received the heated extract from the castrated rats.

Table 2 shows the percentage of ovulated mice and the average of ova in the oviducts in the groups received the heated urinary extract of the intact and the castrated rats with and without testosterone. The differences in the ovulation percentage and the number of the ovulated ova between the castrated animals treated with and without testosterone were not significant.

These findings indicate that GIS excretion in male rats was strongly suppressed by castration and treatment of testosterone at the dose used in the present study had no effect on the decreased excretion of GIS in the orchiectomized rats.

\section{Discussion}

The pineal powder contains, in addition to melatonin, substances which exert antigonadotropic effects (Benson et al., 1971; Soffer et al., 1965; Moszkowska 1965). The authors have previously found that the urinary excretion of GIS was absent or significantly reduced in the pinealectomized male adult rats (Ota et al., 1971). Therefore, the pineal is suggested as a possible secreting organ of GIS. The authors also observed that GIS decreased in the urine of hypophysectomized rats (Ota et $a l ., 1971)$. This finding suggests that the pituitary might be involved in the excretion of GIS 
and it was proposed that the reason of the decreased excretion of GIS from the pineal might be 1) due to the reduced GIS-secreting function in the pineal caused directly by hypophysectomy or 2) that the need of GIS has disappeared because of the lack of gonadotropins.

The testis produces androgens which exert a negative feedback on the hypothalamicpituitary system, thereby inhibiting secretion of pituitary gonadotropins. This inhibitory feedback is released by castration and thus the production of gonadotropins in the pituitary is increased (Yamamoto et al., 1970). It was found that, in the castrated male rats, a rapid rise in the plasma $\mathrm{LH}$ content during the period 0 to $24 \mathrm{hr}$. occurred and, subsequently, the level rose slowly up to the 20th day at which date a plateau level was reached (Blackwell and Amoss, 1971). If the hypothesis that the decreased GIS excretion is due to the lack of gonadotropins is correct, then the excretion of GIS should be elvated or at least unchanged in the castrated rats in which the pituitary gonadotropins is supposed to be increased.

However, the findings obtained in the present study indicate that castration resulted in a significant decrease of gonadotropininhibiting effects of the urinary extract of male rats.

Clementi et al. (1965) reported that, in castrated female rats, pineal cells contained very high levels of RNA, which would suggest that these cells are active. They also observed the histological picture of depressed function of the pineal cells in the estrogen-treated animals. Fiske et al. (1962) found a slight increase of the pineal weight in the orchiectomized rats as compared to the unoperated rats. The authors have observed in the histological studies that the function of the pineal gland is decreased in hypophysectomized female rats and that a similar but lesser change is induced in ovariectomized rats (Satodate et al., 1970). However, a relation of the pineal function to GIS has not been stud- ied.

Fogel and Soffer (1967) observed that the administration of testosterone to two young men resulted in the complete suppression of the urinary excretion of gonadotropin, while the urinary concentration of GIS remained unaltered and that the administration of a smaller amount of estradiol showed similar effects to that observed with the administration of testosterone. With a larger dose of estradiol, however, the results were quite different. In this case, both the urinary gonadotropin and the inhibitor contents were suppressed.

Although testosterone was given only three times a week in the present study, the dose of testosterone injected was considered to be remarkably higher than the daily endogenous production of testosterone in male rats. Administration of testosterone inhibits the rise of the pituitary and plasma luteinizing hormone levels induced by castration in rats (Bogdanove, 1967). However, treatment of testosterone at the dose which was employed in the present study had no effect on the restoring of the excretion of GIS.

From the data obtained from the present study, however, no conclusion could be drawn on the mechanism of secretion of GIS. It seems that the pineal secretes GIS and melatonin, the latter being controlled by light (Axelrod et al., 1965; Wurtman et al., 1963). It was recently found that the excretion of GIS is not affected by blindness in rats (Ota and Obara, 1971). At present, the mechanism of the secretion of GIS is obscure. It would seem that the existence of the pituitary and the testes is necessary for the secretion of GIS from the pineal. The relationship between the pineal and the testes or the pituitary would be quite complicated.

\section{Acknowledgements}

The authors are indebted to Miss Haruyo Yamaya and Miss Eiko Shimizu for their technical assistance. 
PMS and HCG were kindly supplied by The Teikoku Zoki Company, Tokyo, and Mochida Pharmaceutical Co. Ltd., Tokyo.

\section{References}

Axelrod, J., R. J. Wurtman and S. H. Snyder (1965). J. Biol. Chem. 240, 940.

Benson B., M. J. Matthews and A. E. Rodin (1971). Life Sciences 10, Part 1, 607.

Blackwell, R. E. and M. S. Amoss, Jr. (1971). Proc. Soc. Exper. Biol. Med. 136, 11.

Bogdanove, E. M. (1967). Anat. Rec. 157, 117. Clementi, F., F. Franschini, E. Muller and A. Zanoboni (1965). Prog. Brain Res. 10, 585.

Fiske, V. M., J. Pound and J. Putnam (1962). Er:docrinology 71, 130.

Fogel, M., and L. J. Soffer (1967). Am. J.
Obst. and Gynec. 98, 86.

Johnsen, S. G. (1958). Acta endocrinol. 28, 69.

Moszkowska, A. (1965). Prog. Brain Res. 10, 564.

Ota, M., K. S. Hsieh and K. Obara (1970). Endocrinol. Japon. 17, 333.

Ota, M., K. S. Hsieh and K. Obara (1971). Endocrinology 88, 816.

Ota, M., and K. Obara (1971). Endocrinol. Japon. 18, 531

Satodate, R., K. Sasaki and M. Ota (1970). Arch. Neurol. 23, 238.

Soffer, L. J., M. Fogel and A. Rudavsky (1965). Acta. endocrinol. 48, 561.

Wurtman, R. J., J. Axelrod and L. Phillips (1963). Science 142, 1071.

Yamamoto, M., N. D. Diebel and E. M. Bogdanove (1970). Endocrinology 86, 1102. 